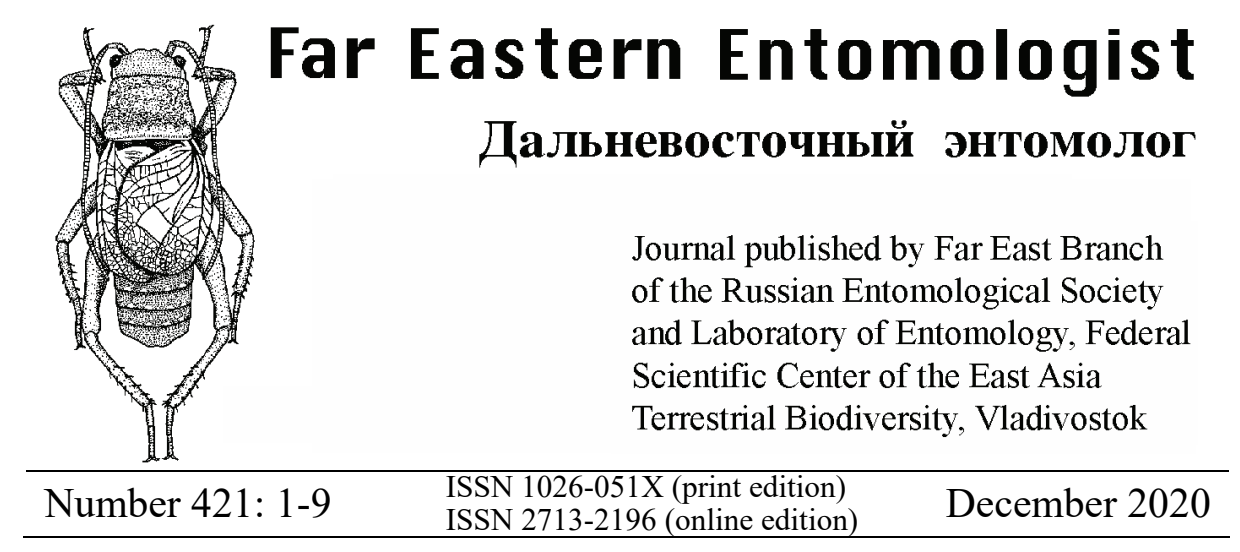

https://doi.org/10.25221/fee.421.1

http://zoobank.org/References/068C9BA9-8E1A-43D3-8126-CCB617AEA9BC

\title{
THREE NEW SPECIES OF VELVET ANTS FROM \\ THE TRIBE SMICROMYRMINI (HYMENOPTERA: MUTILLIDAE) WITH UNUSUAL COLOR SYNDROME
}

\begin{abstract}
A. S. Lelej
Federal Scientific Center of the East Asia Terrestrial Biodiversity, Far East Branch of the Russian Academy of Sciences, Vladivostok, 690022, Russia.E-mail: lelej@biosoil.ru

Summary. Ephucilla hejunhuai sp. n. (China: Guangdong), Promecilla ovtchinnikovi sp. n. (Pakistan: Khyber Pakhtunkhwa), and Smicromyrme (Eremotilla) burgeri sp. n. (India: Karnataka) are described and illustrated. These new species have second metasomal tergum with ferruginous-red cuticle, color pattern which approximates Eastern mimicry ring in North America.

Key words: Hymenoptera, Mutillidae, taxonomy, new species, color syndrome, mimicry rings, aposematism, Oriental Region.

А. С. Лелей. Три новых вида ос-немок из трибы Smicromyrmini (Hymenoptera: Mutillidae) с необычной цветовой окраской // Дальневосточный энтомолог. 2020. N 421. C. 1-9.

Резюме. Описываются Ephucilla hejunhuai sp. n. (Китай: Гуандун), Promecilla ovtchinnikovi sp. n. (Пакистан: Хайбер-Пахтунхва) и Smicromyrme (Eremotilla) burgeri sp. n. (Индия: Карнатака). Эти новые виды имеют второй метасомальный тергит с ржаво-красной кутикулой, цветовой синдром, который напоминает Восточное кольцо мимикрии в Северной Америке.
\end{abstract}




\section{INTRODUCTION}

The Smicromyrmini is one of the abundant in species tribe in the subfamily Mutillinae and includes 26 genera (Brothers \& Lelej, 2017). The females of these genera have different coloration and setal markings. Repeated color patterns in velvet ants have recently been used to establish the World's largest recognized Müllerian mimicry complexes (Wilson et al., 2012, 2015, 2018). To this point, at least 330 North American and 250 African taxa have been found to belong to eight and four mimicry rings, respectively. Of the 247 East Asian mutillid species 224 expressed the Black-headed Color Syndrome (BHCS) and 14 expressed the Redheaded Color Syndrome (RHCS) and nine have other color patterns (Okayasu et al., 2018). Females with BHCS and RHCS have a reddish mesosoma and a blackish metasoma with whitish markings. The BHCS is also common in the Palaearctic and Neotropical fauna of the Mutillidae, while the RHCS is less common. Three new species from the tribe Smicromyrmini with reddish second metasomal tergum and mesosoma have unusual in the Oriental fauna color syndrome.

\section{MATERIAL AND METHODS}

The following abbreviations are used for material discussed in this study: IBSS Federal Scientific Center of the East Asia Terrestrial Biodiversity (formerly Institute of Biology and Soil Science), Vladivostok, Russia; MZUF - Università di Firenze, Museo Zoologico "La Specola", Florence, Italy; ZIN - Zoological Institute of Russian Academy of Sciences, St Petersburg, Russia.

The classification of the Mutillidae follows Brothers and Lelej (2017). The following abbreviations are used: S1, S2, S3, etc., to denote the first, second, third, etc. metasomal sterna; T1, T2, T3, etc., to denote the first, second, third, etc. metasomal terga. Photographs were taken with an Olympus SZX16 stereomicroscope and an Olympus DP74 digital camera, and then stacked using Helicon Focus software. The final illustrations were post-processed for contrast and brightness using Adobe $\mathbb{}$ Photoshop $^{\mathrm{TM}}$ software.

\section{DESCRIPTION OF NEW SPECIES}

Genus Ephucilla Lelej, 1995

Ephucilla Lelej, 1995: 3, 10.

Type species: Mutilla naja Zavattari, 1913, đ̂, by original designation.

SPECIES INCLUDED. The genus includes 13 species in Oriental Region (Pagliano et al., 2020). A new species E. hejunhuai sp. n. is described here.

\section{Ephucilla hejunhuai Lelej, sp. n.}

http://zoobank.org/NomenclaturalActs/BB574DEA-C989-429C-974A-FBB37AF053C6

Figs 1-3

TYPE MATERIAL. Holotype - , China: Guangdong, Xiang Tai Shan near Guangzhou, near wood house, 7.VIII 2016, A. Lelej \& V. Loktionov [IBSS]. 
DIAGNOSIS. FEMALE. Mesosoma long, $1.40 \times$ maximal width, with more or less parallel sides. Scutellar scale distinct, nail-like. T2 except black transverse preapical band and T3 with ferruginous-red cuticle. Pygidial area slightly convex, glabrous, weakly carinated laterally. T2 posterad and T3 with band of yellowish setae. MALE unknown.

DESCRIPTION. FEMALE. Body length $7.5 \mathrm{~mm}$. Ratio of head width and pronotal maximal width 90:90. Ratio of mesosoma length and pronotal maximal width 125:90. Inner margin of mandible with two weak teeth near apex. Clypeus with strong transverse setose carina which limit anterior concave shiny part, basally subtriangular, elevated, with median tubercle. Antennal tubercle carinated above; first flagellomere $0.9 \times$ as long as its maximal width, $1.1 \times$ as long as flagellomere 2. Genal carina distinct, forming small tooth at hypostomal carina junction. Frons, vertex and gena with dense coarse punctures. Humeral angle of mesosoma prominent. Ratios of width at humeral angle, widest point of pronotum, anterior spiracle, propodeal spiracle and narrowest point of propodeum dorsally 80:90:90:80:75. Scutellar scale distinct, nail-like. Mesosoma dorsally slightly convex, with dense coarse punctures larger that on head. Mesopleuron smooth with vertical row of large punctures along mesopleural carina; metapleuron smooth shiny with few punctures along metapleuro-propodeal suture. Propodeum laterally smooth with few shallow punctures. Lateral and posterior propodeal faces separated by wavy carina. Metacoxa carinated mesally. Meso- and metatibia each with two rows of 4-5 weak fuscous spines. Metatibio-tarsal ratios of 75:32:21:16:12:16. T2 with dense small separate punctures, posteriorly smaller and not visible under dense setae. T3-5 with fine dense small punctures. S1 with simple longitudinal carina. S2 with large dense separate punctures. S3-5 posteriorly with fine dense punctures. Pygidial area slightly convex, glabrous, weakly carinated laterally.

Color and setation. Head ferruginous-red, clypeus, mandible, except brownish apex, and antennae, except brownish scape, pedicel and flagellomere 1, ferruginousred; palps pale brown. Mesosoma totally ferruginous-red. Legs ferruginous. Tibial spurs whitish. T1 ferruginous-red. T2, except black transverse preapical band, and T3 with ferruginous-red cuticle. S1-6 ferruginous-red. Frons and vertex with sparse suberect and erect yellowish setae; gena with sparse recumbent yellowish setae. Mesosoma dorsally with sparse suberect blackish setae. Posterior propodeal face with sparse suberect whitish setae. Meso- and metapleuron with few suberect white setae, without supracoxal spot of dense recumbent silver setae. T1 with sparse erect whitish setae. T2 medially with small subbasal spot of yellowish recumbent setae. T2 posterad and T3 with band of yellowish setae. T2, except yellowish spot and band, and T4-5 with sparse recumbent black setae. T6 laterally with long, sparse erect whitish to brownish setae. Lateral felt line on T2 rufous. Metasomal sterna with sparse whitish setae, which form apical fringe on S2-5.

DISTRIBUTION. China (Guangdong).

REMARKS. In having most part of T2 with ferruginous-red cuticle, this species differs from other known Ephucilla.

ETYMOLOGY. The specific name is dedicated to Prof. He Jun-hua (Zhejiang University, Hangzhou, China), for his valuable contribution to the study of Hymenoptera in China. 


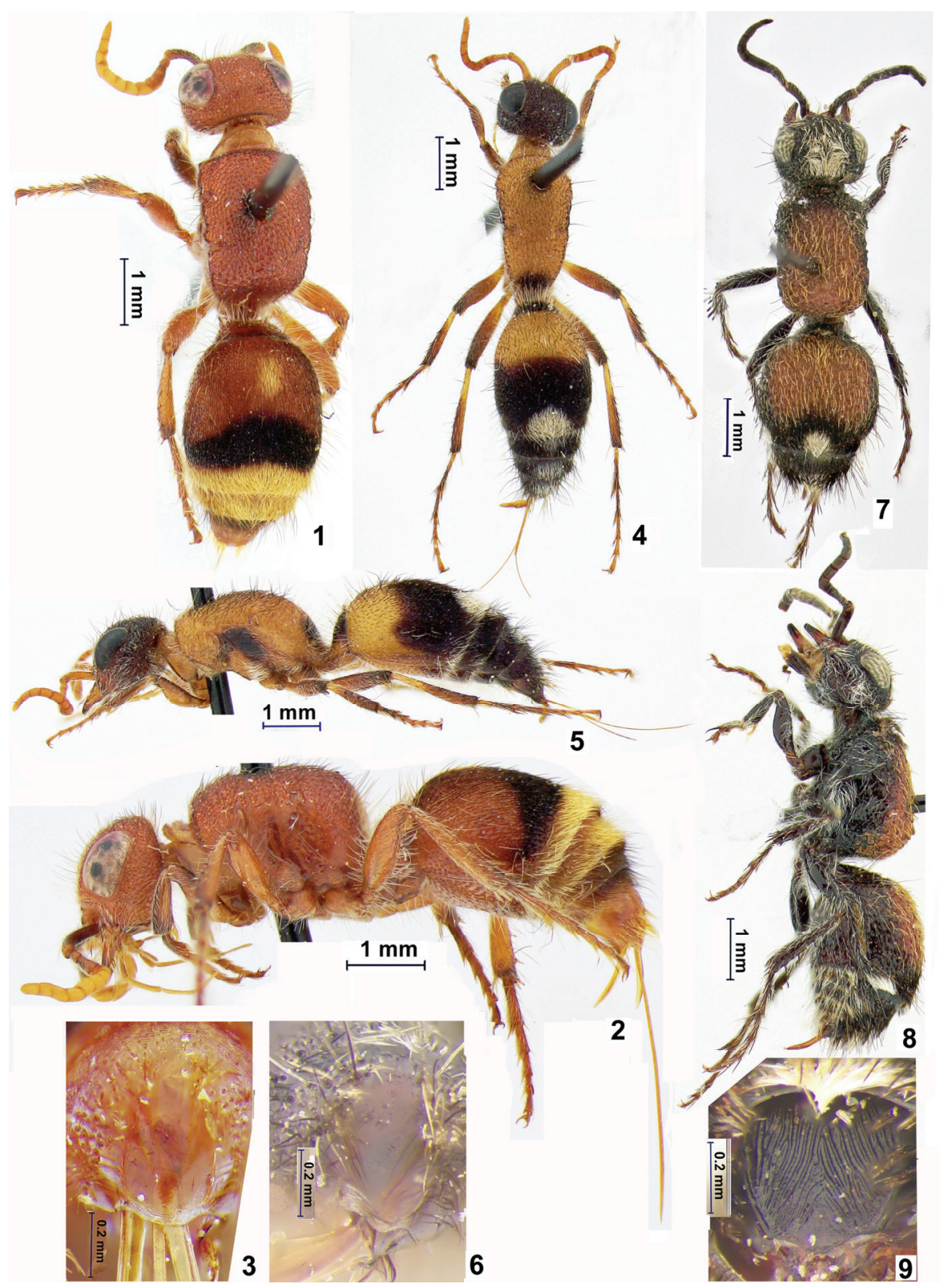

Figs 1-9. 1-3 - Ephucilla hejunhuai sp. n., holotype; 4-6-Promecilla ovtchinnikovi sp. n., + , holotype; 7-9 - Smicromyrme burgeri sp. n., \&, paratype. 1, 2, 4, 5, 7, 8 - habitus (1, 4, 7 - dorsal view; 2, 5, 8 - lateral view); 3, 6, 9- T6, pygidial area. 


\section{Genus Promecilla André, 1902}

Promecilla André, 1902: 14, 40.

Type species: Mutilla regia Smith, 1855, ㅇ, by original designation.

SPECIES INCLUDED. The genus includes 28 species, 21 of them are known from Oriental Region, five from Afrotropical and two (Promecilla primana Skorikov, 1935, 오, Tajikistan, Uzbekistan and P. vinuta (Nagy, 1972), §, Afghanistan) from Palaearctic Region (Pagliano et al., 2020). A new species $P$. ovtchinnikovi sp. n. is described here.

Promecilla ovtchinnikovi Lelej, sp. n.

http://zoobank.org/NomenclaturalActs/9052B540-92A5-440F-9199-F73D2424110E

Figs 4-6

TYPE MATERIAL. Holotype -, , Pakistan: NWF [currently Khyber Pakhtunkhwa] Province, Peshawar, Forestry Campus of Agricultural University, 17.VIII 2005, S.V. Ovtchinnikov [ZIN].

DIAGNOSIS. FEMALE. Mesosoma long, $1.8 \times$ maximal width, convergented posterad; scutellar scale lacking. T2 in basal half and S2 with orange cuticle. Pygidial area shiny matt, slightly convex, not carinated laterally. T2 posterad with large median spot of white setae, T4-5 with median smaller spot of grayish setae. MALE unknown.

DESCRIPTION. FEMALE. Body length $8.0 \mathrm{~mm}$. Ratio of head width and pronotal maximal width $80: 75$. Ratio of mesosoma length and pronotal maximal width 135:75. Mandible with distinct basal widening beneath. Clypeus with strong transverse setose carina which limit anterior concave shiny part, basally subtriangular, elevated, with median tubercle. Antennal tubercle carinated above; first flagellomere $1.1 \times$ as long as its maximal width, $1.2 \times$ as long as flagellomere 2. Genal carina weak, forming small tooth at hypostomal carina junction. Frons, vertex and gena with dense punctures. Humeral angle of mesosoma rounded. Ratios of width at humeral angle, widest point of pronotum, anterior spiracle, propodeal spiracle and narrowest point of propodeum dorsally 60:75:75:67:60. Scutellar scale lacking. Mesosoma dorsally and posterior propodeal face with dense punctures larger that on head. Mesopleuron smooth with vertical row of large punctures along mesopleural carina, propodeum laterally with few shallow punctures. Lateral and posterior propodeal faces separated by wavy carina. Meso- and metatibia each with two rows of 4-5 weak fuscous spines. Metatibio-tarsal ratios of 85:40:27:20:15:20. T2 with dense small elongate separate punctures, posteriorly smaller and denser. T3-5 with fine dense small punctures. S1 with simple longitudinal carina. S2 with sparse large punctures. S3-5 posteriorly with fine dense punctures. Pygidial area slightly convex, not carinated laterally, glabrous matt.

Color and setation. Head brownish-red, clypeus, mandible except apex and antennae ferruginous-red; palps pale brown. Mesosoma ferruginous-red with blackish 
upper part of meso- and metapleuron. Legs ferruginous with apex of femur and most tibia brownish. Tibial spurs whitish. T1 ferruginous-red, brownish posteromedially. T2 in basal half ferruginous-red, S2 ferruginous-red, T2 in apical half, T3-6 black; S3-6 tinted reddish. Frons and vertex with sparse suberect and erect black setae; gena with sparse recumbent whitish setae. Mesosoma dorsally except pronotum with sparse suberect black setae. Pronotum and posterior propodeal face with sparse suberect whitish setae. Meso- and metapleuron with supracoxal spot of dense recumbent silver setae. T1 with sparse erect whitish setae. T2 medially with small subbasal patch of whitish recumbent setae. T2 posterad with large median spot of white setae and fringe of whitish setae. T4-5 with median smaller spot of grayish setae. T2-5 with sparse suberect and recumbent black setae. T6 with long, sparse erect grayish to black setae. Lateral felt line on T2 rufous. Metasomal sterna with sparse whitish setae, which form apical fringe on S2-5.

DISTRIBUTION. Pakistan (North-West Frontier [currently Khyber Pakhtunkhwa] Province).

REMARKS. In having basal half of T2 with ferruginous-red cuticle, this species differs from other known Promecilla. This female may be the opposite sex of the $P$. vinuta (Nagy, 1972), male, described from the Eastern Afghanistan (Nagy, 1972).

ETYMOLOGY. This species is named in honor of tragically died Sergey V. Ovtchinnikov (1958-2007), who collected the holotype.

\section{Genus Smicromyrme Thomson, 1870}

Smicromyrme Thomson, 1870: 208.

Type species: Mutilla rufipes Fabricius, 1787, 9 , by original designation.

SPECIES INCLUDED. There are five subgenera including nominotypical and 266 valid species and 23 valid subspecies which are recognized from the Palaearctic, Afrotropical, and Oriental regions (Pagliano et al., 2020). The Palaearctic fauna are well-divided into subgenera based on characters from both sexes, but especially in males. A new species, S. burgeri sp. n. from the subgenus Eremotilla Lelej, 1985, is described here.

\section{Smicromyrme (Eremotilla) burgeri Lelej, sp. n.}

http://zoobank.org/NomenclaturalActs/041D8CF1-ADF1-4CE5-B354-DB19943B2532

Figs 7-9

TYPE MATERIAL. Holotype - $q$, India: S-India, [Karnataka], $15 \mathrm{~km} \mathrm{SE}$ Bangalore, KT [Käfer trap], 25.VII [19]96, [K.] Werner, [L.] Lorenz leg. [MZUF]. Paratype: S-India, [Karnataka], 15 km N Bangalore, KT, 23-24.VII [19]96, 1 q, [K.] Werner, [L.] Lorenz leg. [IBSS].

DIAGNOSIS. FEMALE. First flagellomere $1.4 \times$ as long as its maximal width, $1.55 \times$ as long as flagellomere 2 . Postgenal bridge with median tubercle and transverse 
microstriae. T2 disc ferruginous-red, laterally and posteriorly brownish to black. Head dorsally with large spot of silver setae, T2 medially with small subbasal spot of golden recumbent setae. T2 posterad with median and lateral spots of silver setae. T4-5 with median spot of silver setae. MALE unknown.

DESCRIPTION. FEMALE. Body length 5.6(holotype)-6.4 mm. Ratio of head width and pronotal maximal width 87:85. Ratio of mesosoma length and pronotal maximal width 120:85. Inner margin of mandible without weak teeth near apex. Clypeus with transverse carina which limit anterior concave shiny part, basally subtriangular, elevated, with median tubercle. Antennal tubercle carinated above; first flagellomere $1.4 \times$ as long as its maximal width, $1.55 \times$ as long as flagellomere 2 . Genal carina weak, forming small tooth at hypostomal carina junction. Postgenal bridge with median tubercle and transverse microstriae. Frons and vertex with dense coarse punctures, gena with dense punctures. Humeral angle of mesosoma prominent. Ratios of width at humeral angle, widest point of pronotum, anterior spiracle, propodeal spiracle and narrowest point of propodeum dorsally 75:85:80:83:70. Scutellar scale distinct, nail-like. Mesosoma dorsally with dense coarse punctures larger that on head. Mesopleuron smooth with distinct mesopleural carina; metapleuron with fine dense punctures. Propodeum laterally with shallow dense punctures. Lateral and posterior propodeal faces separated by wavy carina. Metacoxa carinated mesally. Meso- and metatibia each with two rows of $4-5$ strong fuscous spines. Metatibiotarsal ratios of 70:32:22:18:12:12. T2 with large dense coarse punctures, smaller posteriorly and sparser laterally. T3-5 with dense smaller punctures. S1 with longitudinal carina highest posteriorly. S2 with large dense separate punctures; S3-5 posteriorly with smaller dense punctures. Pygidial area well developed, widened basally, carinated laterally, with divergented striae.

Color and setation. Head black, mandible basally brownish; antennae black, brownish ventrally; palps brownish. Mesosoma black, dorsally ferruginous-red, pronotum brownish; posterior propodeal face ferruginous-red. Legs black. Tibial spurs whitish. T1 brownish. T2 disc ferruginous-red, laterally and posteriorly brownish to black. T3-6 black. S1-6 brownish. Head dorsally with large spot of silver setae, gena with recumbent silver setae. Mesosoma dorsally and posterior propodeal face with sparse suberect yellowish setae, pronotum with sparse recumbent brownish setae. Meso- and metapleuron in lower part with dense recumbent silver setae. T1 with apical median tuft of silver setae. T2 medially with small subbasal spot of golden recumbent setae. T2 posterad with median and lateral spots of silver setae. T4-5 with median spot of silver setae. T2, except golden subbasal and three apical silver spots, with sparse recumbent and suberect yellowish setae; T2 posteriorly, T3, T4-6 laterally with suberect black setae. Lateral felt line on T2 rufous. Metasomal sterna with sparse whitish setae, which form apical fringe on S2-5.

DISTRIBUTION. India (Karnataka).

REMARKS. In having most part of T2 with ferruginous-red cuticle, this species differs from other known Smicromyrme.

ETYMOLOGY. The specific name is dedicated to Frank Burger who collected mutillids in the Indian subcontinent. 


\section{DISCUSSION}

Of the nine East Asian mutillid taxa with other color patterns then BHCS and RHCS, three species from the genus Taiwanomyrme (tribe Trogaspidiini) (Tu et al., 2015; Lelej, 2020) have a body entirely black, except for the second metasomal segment which is reddish. The latter pattern approximates Texan mimicry ring in North America (Wilson et. al., 2015). The discovered three Oriental new species from the tribe Smicromyrmini with reddish second metasomal segment and mesosoma have the color syndrome, which approximates Eastern mimicry ring in North America. These similarly colored insects from disparate continents cannot be treated as members of the same mimicry rings. The color patterns that define these mimicry rings, however, are significant indicators of aposematism, and potentially mimicry (Okayasu et al., 2018).

\section{ACKNOWLEDGMENTS}

I thank Sergey Belokobylskij (Zoological Institute, St Petersburg, Russia), and Museo di Storia Naturale dell'Università degli Studi di Firenze, Florence, Italy, as late Sergey Ovtchinnikov and collectors for the help with the material.

\section{REFERENCES}

André, E. 1902 [“1903”]. Fam. Mutillidae. In: Wytsman, P., Genera Insectorum, Fasc. 11. Bruxelles, 77 pp. +3 pls.

Brothers, D.J., \& Lelej, A.S. 2017. Phylogeny and higher classification of Mutillidae (Hymenoptera) based on morphological reanalyses. Journal of Hymenoptera Research 60: 1 97. DOI: https://doi.org/10.3897/jhr.60.200919

Lelej, A.S. 1995. To the knowledge of East Asian species of the tribe Smicromyrmini Bischoff, 1920 (Hymenoptera, Mutillidae) with description of four new genera and eight new species. Far Eastern Entomologist, 13: 1-28.

Lelej, A.S. 2020. To the knowledge of velvet ants of the genera Artiotilla Invrea, Radoszkowskitilla Lelej and Taiwanomyrme Tsuneki (Hymenoptera, Mutillidae). Far Eastern Entomologist, 410: 1-10. DOI: https://doi.org/10.25221/fee.410.1

Nagy, C.G. 1972. Two new species of Mutillidae (Hymenoptera) from Asia Minor and description of female Mutilla erronea. Bulletin of Iraq Natural History Museum, 5(2): 4-9.

Okayasu, J., Williams, K.A. \& Lelej, A.S. 2018. A remarkable new species of Sinotilla Lelej (Hymenoptera: Mutillidae: Smicromyrmini) from Taiwan and an overview of color diversity in East Asian mutillid females. Zootaxa, 4446(3): 301-324. DOI: https:// doi.org/ 10.11646/zootaxa.4446.3.1

Pagliano, G., Brothers, D.J., Cambra, R., Lelej, A.S., Lo Cascio, P., Matteini Palmerini, M., Scaramozzino, P.L., Williams, K.A. \& Romano, M. 2020 ["2018"]. Checklist of names in Mutillidae (Hymenoptera), with illustrations of selected species. Bollettino del Museo Regionale di Scienze Naturali di Torino, 36(1-2): 5-425.

Thomson, C.G. 1870. Öfversigt af Sveriges rofsteklar. Opuscula Entomologica, 1(2): 202 251.

Tu, B.B., Lelej, A.S. \& Chen, X.X. 2015. Review of the genus Taiwanomyrme Tsuneki, 1993 (Hymenoptera, Mutillidae, Mutillinae), with description of two new species from China. Zootaxa, 4020(3) : 588-600. DOI: http://doi.org/10.11646/zootaxa.4020.3.10 
Wilson, J.S., Jahner, J.P., Forister, M.L., Sheehan, E.S., Williams, K.A. \& Pitts, J.P. 2015. North American velvet ants form one of the world's largest known Müllerian mimicry complexes. Current Biology, 25: 704-706. [R704-R706]. DOI: https://doi.org/10.1016/ j.cub.2015.06.053

Wilson, J.S., Pan, A.D., Limb, E.S. \& Williams, K.A. 2018. African velvet ant (Hymenoptera: Mutillidae) Müllerian mimicry rings reveal the depauperate nature of insectivorous lizards in Africa. PLOS ONE, 13 (1), e0189482. DOI: https://doi.org/10.1371/journal.pone. 0189482

Wilson, J.S., Williams, K.A., Forister, M.L., von Dohlen, C.D. \& Pitts, J.P. 2012. Repeated evolution in overlapping mimicry rings among North American velvet ants. Nature Communications, 3, 1272. DOI: https://doi.org/10.1038/ncomms2275 